\title{
The effect of private investment, exports, imports, inflation and GDP on per capita premium: Evidence from members of OPEC countries
}

\author{
Reza Abedini ${ }^{a^{*}}$ and Roya Darabi ${ }^{\mathbf{b}}$
}

${ }^{a}$ Department of Financial Management, Science and Research Branch, Islamic Azad University, Tehran, Iran ${ }^{b}$ Assistant Professor, Department of Management and Accounting, Islamic Azad University, South Branch, Iran

\begin{abstract}
C H R O N I C L E
Article history:

Received March 25, 2015

Received in revised format 28

March 2015

Accepted 15 May 2015

Available online

May 182015

Keywords:

Export value

Import value

GDP

Private sector investment

Inflation

Insurance per capita

OPEC countries

A B S T R A C T

In this study, we examine the relationship between GDP, export, import, private sector investment and inflation on insurance per capita of OPEC countries. Insurance is a non-banking institution that by making sure and secure, can make and develop manufacturing and service rendering easier. Insurance companies can make financial steady and reduce stress. So, it plays essential role in economy. For this aim, data over the period 2003-2011 is collected. We use regression and SPSS software for analysis. Results for 80 year - country show that there was a positive and significant correlation between GDP, export, import, inflation and insurance per capita, which shows whenever productivity increases, insurance increases too. Results also show that there was a positive relationship between import and insurance per capita. In addition, results show that there was a positive and significant relationship between inflation and dependent variable. However, there was no significant relationship between exports and insurance per capita. The results show that there was no significant relationship between GDP and insurance per capita and finally, there was a non-significant and negative relationship between private sector investment and insurance per capita.
\end{abstract}

\section{Introduction}

The relationship between financial development of the insurance, as part of its financial intermediation, and economic growth have been under several discussions but there has been few consensus among scholars about the economy (Taub,1989; Fanti \& Gori, 2012). Thus the debate about the relationship between insurance development and economic growth seems to be necessary (Ihori et al., 2011). Insurance for non-bank financial institutions builds confidence and security and expands their productive activities and services. In other words, insurance companies, financial stability and reduced anxiety are achieved through compensation. The purpose of this study is to examine the impact of the changing insurance market activities and economic growth in selected countries among (Organization of Petroleum Exporting Countries (OPEC) members, the international oil cartel is to determine whether the relationship between insurance market activity and economic indicators in these countries exists.

\footnotetext{
* Corresponding author.

E-mail address: alireza.abedini88@gmail.com (R. Abedini) 
With the insurance model, one may distribute the consequences of a certain risk across all population (Zhengtang, 2011; Leung, 2001). General access to insurance products is one of the social and economic development indicators. It is a myth that insurance is essential only for the rich and only the rich should be interested in it. Research shows that none but low and moderate income earners can reap maximum benefits from being insured.

Insurance is a major financial asset for both individual households and the whole economy. Life products increase savings, especially long-term ones. The purpose of such savings can be multiple. The most important objective includes educational needs of children and old age protection. When the level of social security and healthcare benefits is becoming lower, the significance of insurance products will be growing. Accelerating economic growth is one of the main objectives of many countries and it has always been the question among economists on how the economy and factors that influence economic growth. Alhassan and Fiador (2014) examined the long-run causal relationship between insurance penetration and economic growth in Ghana over the period 1990-2010.

According to earlier and given the importance of insurance activities in economic growth, in this study, the binding has a number of relevant variables such as stock market turnover, private funds, government spending, inflation, human capital, changes in business rules, per capita GDP growth, the impact of the changing insurance market activities and economic growth in selected countries. Jahangard (2011) analyzed the relationship between economic growth and growth in insurance over the period 19652007. Webb et al. (2002) investigated the effects of banks and insurance on the economy.

According to Arena (2008) insurance market activity can contribute to economic growth, both as financial intermediary and provider of risk transfer and indemnification, by permitting various risks to be managed more effectively and by mobilizing domestic savings. During the past few years, there has been faster trend of growth in insurance market activity, specifically in emerging markets, given the process of financial liberalization and integration, which creates motivation about the overall effect on economic growth. Arena (2008) examined whether there was a causal relationship between insurance market activity, life and nonlife insurance, and economic growth. Using the generalized technique of moments for dynamic models of panel data for 55 countries over the period 1976-2004, he found robust evidence for this relationship. Both life and nonlife insurance, in this study, maintained a positive and significant causal effect on economic growth.

Ward and Zurbruegg (2000) investigated the short- and long-run dynamic relationships exhibited between economic growth and growth in the insurance industry for 9 OECD countries. This was accomplished by performing a cointegration analysis on a unique set of annual data for some real GDP and total real premiums issued in each country over the period 1961-1996. They reported that in some countries, the insurance industry Granger caused economic growth, and in other countries, the reverse hold. In addition, the results indicated that these relationships were country specific and any discussion of whether the insurance industry could promote economic growth would depend on a number of national circumstances. Lee et al. (2013) investigated the link between life insurance activities and economic growth. Cristea et al. (2014) built a correlation between insurance and economic growth in Romania, by taking into consideration the share of gross premium written to GDP, and the average value of the insurance premium spent by an inhabitant across one year. Pradhan et al. (2015) investigated causal relationships between insurance market development, financial development, and economic growth in 34 OECD countries over the period 1988-2012. Insurance market development was described in terms of life, non-life, and total insurance pervasiveness, both by density and penetration. Financial development was a composite index constructed from eight financial development indicators associated with banking and stock markets. They applied a panel vector autoregression model to determine the nature of Granger causality among the variables. The results disclosed that insurance market development specifically and financial market development overall appeared both to be long-run causative factors of economic growth. Moreover, the short-run causality 
results indicated a diverse pattern of short-run adjustment dynamics between the variables, including the possibility of feedback between them in several instances. Hou et al. (2012) studied the effects of financial institutions on economic growth using a panel data for 12 Euro countries. They reported that life insurance penetration and banking development had not had any effect on real outputs. They also argued that the findings were strongly influenced by multi-collinearity among variables of interest.

\section{The proposed study}

The proposed study of this paper suggests the following hypotheses:

(1) There is a significant relationship between GDP per capita and premium.

(2) There is a significant relationship between value of exports and per capita premium.

(3) There is a significant relationship between the value of imports and capital contributions.

(4) There is a significant relationship between private investment and capital contribution.

(5) There is a significant relationship between inflation and per capita premium.

The study has been accomplished using the historical data over the period 2003-2011 and the population includes the following OPEC member countries. The study uses the following regression model to study the proposed study.

$$
\begin{aligned}
\log (\text { Insurance per capita }) & =\mathrm{c}+\alpha_{1} \log (G D P)+\alpha_{2} \log (E X)+\alpha_{3} \log (I M)+\alpha_{4} \log (\text { Inflation }) \\
& +\alpha_{5} \log (\text { Private Invest })+\varepsilon,
\end{aligned}
$$

where

Insurance per capita is calculated by dividing insurance cost for the country for a given year by population of that country. GDP is gross domestic production, EX is export value for a given year for a country, IM is import value for a given year for a country, Inflation represents the rate of inflation for a given year and Private Invest is the value of investment by the private sector of a country. After collecting data, they are imported in EXCEL and then by using SPSS, the analysis is done. In this research, descriptive and inferential statistics will be used to illustrate and test the significance of the hypotheses of the survey. To test the hypothesis of multiple regression and correlation coefficient $t$-test and $\mathrm{F}$ test are employed.

\section{The results}

Table 1 shows the descriptive statistics of the case, as can be seen, the mean of individual premiums per capita in these countries is 7.27. In addition, the distribution of the data seems to close to normal.

\section{Table 1}

The resents of descriptive statistics of the variables for the sample (2003-2011)

\begin{tabular}{lccccccc}
\hline & $\begin{array}{c}\text { Insurance per } \\
\text { capita }\end{array}$ & GDP & EX & IM & Inflation & Private Invest \\
\hline Number & 80 & 80 & 80 & 80 & 80 & 80 & 32.9197 \\
mean & 7.2707 & 20226.4872 & 83856.3622 & 47033.1486 & 8.8888 & 27.2083 \\
mid & 7.0723 & 10105.0000 & 63990.0000 & 33664.9745 & 5.3000 & 200 \\
Standard deviation & .97245 & 20057.03191 & 73806.71951 & 44703.39062 & 7.87756 & 19.63522 \\
& 25 & 6.4617 & 7019.2500 & 29947.0000 & 17408.5996 & 2.8250 & 16.5575 \\
Percentile & 50 & 7.0723 & 10105.0000 & 63990.0000 & 33664.9745 & 5.3000 & 27.2083 \\
& 75 & 8.0951 & 38561.0000 & 100383.7500 & 59157.2500 & 13.5250 & 43.1054 \\
\hline
\end{tabular}


One of the assumptions of regression is the normality of the model residuals. The final regression model was met to estimate the ultimate pattern of data on independent variables. Table 2 shows the results of Kolmogorov - Smirnov test.

Table 2

Test Kolmogorov - Smirnov

\begin{tabular}{lcccccc}
\hline & \multicolumn{5}{c}{ Normal parameters } & \multicolumn{5}{c}{ Absolute differences } \\
\hline Variable & Mean & Std. dev. & Absolute & Positive & Negative & K-S (Sig.) \\
Statistics & 2.2707 & 0.97245 & 0.111 & 0.111 & -0.067 & $0.991(0.28)$ \\
\hline
\end{tabular}

According to the results of Table 2, we may confirm that the variable of the study is normally distributed. Table 3 presents the summary of the results of our survey.

Table 3

The results of regression analysis

\begin{tabular}{lccccc}
\hline Model & $\mathrm{R}$ & $\mathrm{R}^{2}$ & Adjusted $\mathrm{R}^{2}$ & Standardized errors & Durbin-Watson statistical \\
\hline 1 & 0.876 & 0.768 & 0.750 & 0.47289 & 1.655 \\
\hline
\end{tabular}

According to the results of Table 3, Adjusted R-Square is equal to 0.75, which means the independent variable describes approximately $75 \%$ of the changes on dependent variable. Durbin-Watson is within desirable value, which means there is no correlation among residuals. Table 4 demonstrates the summary of the ANOVA test.

Table 4

Table test of significance of the regression

\begin{tabular}{lccccc}
\hline model & Sum of squares & df & Mean square & F & sig \\
\hline Regression & 47.406 & 5 & 9.481 & 42.397 & 0.000 \\
Residual & 14.312 & 64 & 0.224 & & \\
\hline Total & 61.718 & 69 & & & \\
\hline
\end{tabular}

According to Table 4, since 95\% of the calculated F-statistics of the regression equation is greater than the $\mathrm{F}$ value obtained from Table 1, this result supposes the hypo that says (regression model is not significant) is rejected. It is clear that in case of rejection, the regression is significant.

Table 5

The results of regression analysis

\begin{tabular}{|c|c|c|c|c|c|}
\hline & \multicolumn{2}{|c|}{$\begin{array}{l}\text { Unstandardized } \\
\text { Coefficients }\end{array}$} & \multirow{2}{*}{$\begin{array}{c}\begin{array}{c}\text { Standardized } \\
\text { Coefficients }\end{array} \\
\text { Beta } \\
\end{array}$} & \multirow[b]{2}{*}{$\mathrm{t}$} & \multirow[b]{2}{*}{ Sig. } \\
\hline & B & Std. Error & & & \\
\hline Intercept & 5.955 & .159 & & 37.501 & .000 \\
\hline GDP & $-9.659 \mathrm{E}-7$ & .000 & -.020 & -.210 & .835 \\
\hline EX & 2.361E-6 & .000 & .190 & 1.653 & .103 \\
\hline IM & $1.107 \mathrm{E}-5$ & .000 & .544 & 4.537 & .000 \\
\hline Inflation & .073 & .008 & .609 & 9.269 & .000 \\
\hline Private Invest & -.001 & .005 & -.011 & -.105 & .917 \\
\hline
\end{tabular}

The results obtained are summarized in Table 5 indicate that, there was a positive and significant correlation between GDP, export, import, inflation and insurance per capita, which shows whenever productivity increases we expect an increase on insurance. Results also show that there was a positive relationship between import and insurance per capita. So, hypothesis 3 is approved. Moreover, results show that there was a positive and significant relationship between inflation and dependent variable, so, hypothesis 4 is also approved. However, there is no significant relationship between exports and insurance per capita, so, hypothesis 2 is rejected. Moreover, results show that there is no significant 
relationship between GDP and insurance per capita, so hypothesis 1 is also rejected. FFinally, there is a non-significant and negative relationship between private sector investment and insurance per capita, so, hypothesis 5 is rejected.

\section{Discussion and conclusions}

Insurance, non-banking financial institutions that build confidence and security, expand productive activities and services. In other words, insurance companies, financial stability and reduce anxiety is accomplished through compensation. Thus the debate about the relationship between insurance development and economic growth seems to be necessary. For this purpose, data on variables from 2003 to 2011 were used. The results show that there was a positive and significant correlation between GDP, export, import, inflation and insurance per capita, which shows whenever productivity increases, insurance also increases. Results show that there was a positive relationship between import and insurance per capita. Therefore, hypothesis 3 is approved. In addition, results show that there was a positive and significant relationship between inflation and dependent variable, so, hypothesis 4 is also approved. But there is no significant relationship between exports and insurance per capita, so, hypothesis 2 is rejected. Moreover, the results show that there was no significant relationship between GDP and insurance per capita, so hypothesis 1 is also rejected. Finally, there is a non-significant and negative relationship between private sector investment and insurance per capita, so, hypothesis 5 is rejected.

\section{Acknowledgement}

The authors would like to thank the anonymous referees for constructive comments on earlier version of this paper.

\section{References}

Alhassan, A. L., \& Fiador, V. (2014). Insurance-growth nexus in Ghana: An autoregressive distributed lag bounds cointegration approach. Review of Development Finance, 4(2), 83-96.

Arena, M. (2008). Does insurance market activity promote economic growth? A cross-country study for industrialized and developing countries. Journal of Risk and Insurance, 75(4), 921-946.

Cristea, M., Marcu, N., \& Cârstina, S. (2014). The relationship between insurance and economic growth in Romania compared to the main results in Europe-A theoretical and empirical analysis. Procedia Economics and Finance, 8, 226-235.

Fanti, L., \& Gori, L. (2012). Economic growth and stability with public pay-as-you-go pensions and private intra-family old-age insurance. Research in Economics, 66(3), 219-229.

Hou, H., Cheng, S. Y., \& Yu, C. P. (2012). Life Insurance and Euro Zone's Economic Growth. Procedia-Social and Behavioral Sciences, 57, 126-131.

Ihori, T., Kato, R. R., Kawade, M., \& Bessho, S. I. (2011). Health insurance reform and economic growth: Simulation analysis in Japan. Japan and the World Economy, 23(4), 227-239.

Jahangard, E. (2011). Insurance and economic growth: The case of Iran's economy. Journal of Economic Research and Policies, 19(59), 53-79.

Lee, C. C., Lee, C. C., \& Chiu, Y. B. (2013). The link between life insurance activities and economic growth: Some new evidence. Journal of International Money and Finance, 32, 405-427.

Leung, C. K. Y. (2001). Productivity growth, increasing income inequality and social insurance: the case of China?. Journal of Economic Behavior \& Organization, 46(4), 395-408.

Pradhan, R. P., Arvin, M. B., \& Norman, N. R. (2015). Insurance development and the finance-growth nexus: Evidence from 34 OECD countries. Journal of Multinational Financial Management, 31, 122.

Taub, B. (1989). Insurance and economic growth. Journal of Public Economics,38(2), 249-264.

Ward, D., \& Zurbruegg, R. (2000). Does insurance promote economic growth? Evidence from OECD countries. Journal of Risk and Insurance, 67(4), 489-506. 
Webb, I. P., Grace, M. F., \& Skipper, H. D. (2000). The effect of banking and insurance on the growth of capital and output (Doctoral dissertation, Georgia State University).

Zhengtang, Z. (2011). Natural catastrophe risk, insurance and economic development. Energy Procedia, 5, 2340-2345. 